\title{
INTRODUCTION
}

\section{The Sounds of Marshallese}

General advice on mastering the sounds

The Marshallese sound system is quite different from that of English, and has a number of sounds for which there are no close equivalents in English. The best general advice we can give is to imitate your teacher closely. And, as one linguist has pointed out, if you sound good to yourself at first, this is probably a bad sign, and means that you are substituting English sounds in a language where they do not belong. If, on the other hand, your first attempts at close mimicry of your teacher make you sound odd to yourself, this probably means that you are getting out of the mold of your English sound habits and nearer to the Marshallese mark. What you want to do is to establish an entirely new set of sound habits. Strive for perfection from the beginning. Avoid practicing wrong habits, for, as with all habits, the longer they are practiced, the harder they are to break. All physiologically normal Marshallese children learn perfectly good pronunciation, as you could have had you been born there. Your job now is somewhat complicated by the fact that you have settled into English sound habits, but it is far from impossible. Many adults do learn foreign languages with nearnative pronunciation, and the chances are that you can achieve this in Marshallese, if you strive from the beginning.

The task is twofold: 1) you will need to learn to hear new sound signals that your English ears had learned to ignore, and 2) you will need to learn articulations abandoned with the babbling stage. Put yourself in a babbling frame of mind again, and you will have the flexibility to begin sounding good to Marshallese ears.

Sounds and Spellings

No spelling system can represent on paper everything that you will need to listen for. In fact, looking at a spelling on paper too soon can give you a false sense of security and close your ears to the many important 
$\mathrm{xii}$

parts of the sounds that are not shown on paper. This is why all new material in these lessons should be drilled extensively orally before it is ever seen in print.

But print has its value as a memory device, especially for adult minds that have become dependent on it. With this in mind, we have provided written materials for each lesson. Two different spellings are used. The first is a phonetic spelling based on a scientific analysis of the language. Although it does not indicate a11 the nuances of sound you will need to learn in order to avoid a foreign accent, it does show all the differences that are significant for distinguishing one word from another in Marshallese. Then, for reference and use after you have become tuned in to the sound to the point where discrepancies on paper will not trip you up, you are given a sample of one of the spellings used by Marshallese writers. Marshallese spelling is like English in that the letters do not fit the sounds too well, and the situation is further complicated by the fact that Marshallese literary tradition is not long enough for one standardized spelling to have developed.

Thus our reasons for giving you a scientific phonetic spelling in addition to a typical Marshallese spelling are two: 1) the latter would lead you astray in many ways as to the sounds, and 2) there is no one agreedupon Marshallese spelling. Most Marshallese spellers have many practices in common, as you will note when you come to read some of their products, but mixed in with these are a number of idiosyncracies. Our phonetic spelling is sufficiently different from usual Marsha11ese spelling that you will probably have little trouble with confusing the two; usually it appears on the right hand side of the page.

\section{Marshallese Dialects}

Considering the vast area covered by the Marshalls, the language is amazingly homogeneous, but there are two major dialects which differ sometimes (but not often) in the choice or the pronunciation of a word. These two dialects coincide with the two chains of islands: the eastern or Ratak chain, and the western or Rylik chain. However, at focal centers like Majuro, or Ebeye on Kwajalein, one finds speakers of both dialects. The western (Rulik) dialect has slightly higher prestige today, since the early missions were located in that 
xiii

chain, and that dialect was used in translations of the Bible, but in some ways the eastern (Ratak) dialect is more conservative and interesting to the linguist. Do not be overly concerned if your teacher uses different words or expressions, or pronounces words different1y from what is indicated in your printed lesson materials. When this happens, do not challenge him in any way, but simply make a note of the divergence for your own later reference. Eventually you will want to become conversant with both dialects, and if your study of the 1anguage goes deep enough, you will find that there are minor dialects within the major dialects: Mejit, for example is divergent in the east, as in Ujelang in the west. The differences you note will be of the same order as some of the following within English: paiz vs. bucket, polecat vs. skunk, faucet vs. spigot vs. tap, either, advertisement, garage, Caribbean, and Hawaii.

Developing a scientific outlook on language and culture

All these lessons can hope to do is to introduce you to the sounds, grammar, and vocabulary of Marshallese, in that order of priority. For without the signals, you can learn neither the grammar nor the vocabulary, and without the grammar, you cannot learn vocabulary in any depth. At the end of this course you should be tuned in to the sound signals and have a feel for grammar or sentence construction within a limited vocabulary. The big task of building vocabulary and getting a feeling for denotations and connotations will be yours to do within a Marshall Islands context. You will then find much these lessons did not contain or only hinted at. You will find Marshallese linguistic taboos quite different from ours, with double-entendres the national pastime, off-color (from an American point of view) joking in certain mixed groups, but the strict avoidance of the same in other groups (even all-male) where taboo relatives are present. Through the language you will get much closer to Marshallese life and culture.

The vowe 1 sounds

Basically there are four vowe1s in Marshallese. The plain values of the three familiar letters used in the phonetic spelling--a, e, $\underline{i}_{--a r e}$ close to their short values in English, as in sat, set, sit. The fourth vowel symbol used, an ampersand $(\&)$, should be considered a cross between $e$ and $\underline{i}$, with a plain value somewhere between that of the vowels in set and sit. 
xiv

\begin{tabular}{|c|c|c|}
\hline Vowe 1 & \multicolumn{2}{|c|}{ Examples } \\
\hline$\&$ & $\begin{array}{l}m \& j \\
n \& n \\
p \& n \\
1 \& p \\
y \& 1 \\
-j \& y \& 1 \\
y \& j \\
j \& y j \& y\end{array}$ & $\begin{array}{l}\text { dead } \\
\text { a tree: Morinda citrifolia } \\
\text { hard } \\
\text { egg } \\
\text { nest } \\
\text { three (with pl. pronouns) } \\
\text { up; east } \\
\text { writing }\end{array}$ \\
\hline $\mathrm{a}$ & $\begin{array}{l}\text { dan } \\
\text { maj } \\
\text { pad } \\
\text { yal } \\
\text { mayal } \\
\text { may } \\
\text { jayan } \\
\text { jan }\end{array}$ & $\begin{array}{l}\text { water, liquid } \\
\text { eye } \\
\text { stay } \\
\text { shave } \\
\text { axe; metal } \\
\text { breadfruit } \\
\text { cent (s) } \\
\text { from }\end{array}$ \\
\hline e & $\begin{array}{l}\text { men } \\
\text { yen } \\
\text { leyen } \\
\text { yej } \\
\text { meyej } \\
\text { mey } \\
\text { jeyen } \\
\text { jen }\end{array}$ & $\begin{array}{l}\text { thing } \\
\text { let him } \\
\text { fruit } \\
\text { he is (doing something) } \\
\text { mate on a ship } \\
\text { which } \\
\text { chain } \\
\text { let's }\end{array}$ \\
\hline$i$ & $\begin{array}{l}\text { dim } \\
\text { nin } \\
\text { lij } \\
\text { jil } \\
\text { jinjin } \\
\text { pil } \\
\text { yin } \\
\text { niy }\end{array}$ & $\begin{array}{l}\text { tight } \\
\text { to pound } \\
\text { to mash } \\
\text { dark colored } \\
\text { to curse } \\
\text { drop of liquid } \\
\text { I am to; of } \\
\text { coconut }\end{array}$ \\
\hline
\end{tabular}

The above can be considered the basic or plain values for the vowels. As we shall see, these become modified in two different ways when the vowels stand next to certain other consonants. But in order to explain this, we shall first have to introduce the consonant sounds.

The consonant sounds

The consonant sounds are best viewed in three groups, according to their effect on neighboring vowels: the PLAIN or LIGHT consonants, the HEAVY consonants, and 
the ROUNDED consonants. A11 the consonants in the above examples for the vowel sounds have been light consonants; these keep neighboring vowels at the plain values illustrated in the examples. Some consonants are passed over quickly in pronunciation, while others are held and dwelt on a bit before passing on. Those that are held longer are written doubly in the phonetic spelling.

\section{Light consonants}

\begin{tabular}{|c|c|c|c|}
\hline d & $\begin{array}{l}\text { a trilled r-sound, } \\
\text { but with the } \\
\text { tongue trilled } \\
\text { against the upper } \\
\text { teeth instead of } \\
\text { against the roof } \\
\text { of the mouth, as } \\
\text { for } r\end{array}$ & $\begin{array}{l}\text { diy } \\
\text { y\&d } \\
\text { m\&d\&y } \\
\text { yeddap }\end{array}$ & $\begin{array}{l}\text { bone } \\
\text { baby mat } \\
\text { soft coconut meat } \\
\text { it sticks }\end{array}$ \\
\hline j & $\begin{array}{l}\text { like a Russian pal- } \\
\text { atalized t-sound; } \\
\text { sometimes similar } \\
\text { to English s, sh, } \\
\text { ch, j, } z \text {, for ali } \\
\text { of which it sub- } \\
\text { stitutes in loan } \\
\text { words }\end{array}$ & $\begin{array}{l}\text { jep } \\
1 a j \\
m i j \& l \\
m \& j j \& y\end{array}$ & $\begin{array}{l}\text { cheek } \\
\text { wild } \\
\text { thick } \\
\text { opening between } \\
\text { islets }\end{array}$ \\
\hline 1 & $\begin{array}{l}\text { no equivalent in } \\
\text { English; an } 2 \text {-sound } \\
\text { made with the } \\
\text { tongue tip touching } \\
\text { the upper teeth }\end{array}$ & $\begin{array}{l}\text { liy } \\
\text { yil } \\
\text { malim } \\
\text { palley }\end{array}$ & $\begin{array}{l}\text { the letter ' } 1 \text { ' } \\
\text { taro sprout } \\
\text { permitted } \\
\text { foreigner }\end{array}$ \\
\hline n & $\begin{array}{l}\text { like the m in } \\
\text { English music or } \\
\text { the me in meow; } \\
\text { when long, like } \\
\text { the mb m in dumb } \\
\text { mute }\end{array}$ & $\begin{array}{l}\text { m\&y } \\
\text { yim } \\
\text { jeman } \\
\text { yemmed }\end{array}$ & $\begin{array}{l}\text { fortress } \\
\text { and } \\
\text { his father } \\
\text { it is overripe } \\
\text { (breadfruit) }\end{array}$ \\
\hline & $\begin{array}{l}\text { close to the English } \\
n \text { in need, but with } \\
\text { the tongue against } \\
\text { the upper teeth; } \\
\text { when long, like the } \\
n \text { 's in ten nests }\end{array}$ & $\begin{array}{l}\text { ney } \\
\text { yen } \\
\text { yan\&y } \\
\text { yennan }\end{array}$ & $\begin{array}{l}\text { leg, foot } \\
\text { let him } \\
\text { islet } \\
\text { it is moldy }\end{array}$ \\
\hline & $\begin{array}{l}\text { like the } b \text { in } \\
\text { English beauty; } \\
\text { when long, like }\end{array}$ & $\begin{array}{l}\text { pap } \\
\text { yip }\end{array}$ & $\begin{array}{l}\text { coconut frond } \\
\text { (midrib) } \\
\text { crooked }\end{array}$ \\
\hline
\end{tabular}


xvi

$\begin{array}{lll}\text { the p's in keep } & \text { jap\&y } & \text { wooden bow1 } \\ \text { pure } & \text { yippan } & \text { with him } \\ \text { y ometimes sounds } & \text { yiy } & \text { at } \\ \text { like Englishy, } & \text { yay\&y } & \text { the letter 'e' } \\ \text { but more often } & \text { p\&yin } & \text { his arm, hand } \\ \text { heard only in its kiyyeh } & \text { now } \\ \text { effect on neighbor- } & & \\ \text { ing vowels } & \end{array}$

Heavy consonants

The heavy consonants shift neighboring vowels from their plain values illustrated above roughly as follows: a becomes $a h$, e becomes $u h$, and $\&$ and $i$ come to resemble varieties of the comic strip ugh! without lip rounding. A b can be considered a heavy $\mathrm{p} ; \mathrm{h}$ a heavy $\mathrm{y}$; $\underline{\underline{z}}, \underline{\mathrm{h}}$, and $\overline{\mathrm{n}}$ can be considered heavy $\underline{1}, \underline{\mathrm{m}}, \overline{\mathrm{n}}$, respectively; $\underline{r}$ a heavy $\underline{d}$, and $\underline{t}$ a heavy $\bar{j}$. Both $\underline{k}$ and $g$ belong to the same group in that they also have a heavy effect on neighboring vowels, although they have no light counterparts. (The letter g is used in shorthand fashion for a value close to the $n g$ in singer.)

\begin{tabular}{|c|c|c|c|}
\hline b & $\begin{array}{l}\text { similar to the bw } \\
\text { in bwana; more } \\
\text { like the p's of } \\
\text { top pueblo when } \\
\text { long (double) }\end{array}$ & $\begin{array}{l}\text { bah } \\
\text { kab } \\
\text { kebah } \\
\text { kebbat }\end{array}$ & $\begin{array}{l}\text { say } \\
\text { and; just; cup } \\
\text { copper } \\
\text { get ahead of }\end{array}$ \\
\hline & $\begin{array}{l}\text { softer than the } \\
\text { English } h \text {; often } \\
\text { heard mainly in } \\
\text { its effect on } \\
\text { neighboring } \\
\text { vowels }\end{array}$ & $\begin{array}{l}\text { hak } \\
\text { tah } \\
\text { hah\&h } \\
\text { haheh }\end{array}$ & $\begin{array}{l}\text { frigate bird } \\
\text { what? } \\
\text { mine, my } \\
\text { swim }\end{array}$ \\
\hline $\mathrm{g}$ & $\begin{array}{l}\text { like the ng in sing } \\
\text { or singer (but } \\
\text { without the extra } \\
\text { 'hard' g-sound in } \\
\text { longer and finger) }\end{array}$ & $\begin{array}{l}\text { gah } \\
\text { hag } \\
\text { kagir } \\
\text { kagget }\end{array}$ & $\begin{array}{l}\text { I } \\
\text { wind, breeze } \\
\text { be1t } \\
\text { struggle, } \\
\text { persevere }\end{array}$ \\
\hline & $\begin{array}{l}\text { like the of out, } \\
\text { but without the } \\
\text { puff of breath of } \\
\text { the English conso- } \\
\text { nant; like the ck } \\
c \text { of wreck cars } \\
\text { when double }\end{array}$ & $\begin{array}{l}\text { kał } \\
\text { łak } \\
\text { hakeh } \\
\text { hakkik }\end{array}$ & $\begin{array}{l}\text { loincloth, } \\
\text { diaper } \\
\text { to lock } \\
\text { but (how about...) } \\
\text { fingernail (Ratak) }\end{array}$ \\
\hline
\end{tabular}


xvii

$\mathbf{z}$

something like the
$l$ of lost or ball,
with the tongue
touching the roof
of the mouth; not
like the $l$ of least

in like the meo of someone

$\begin{array}{ll}\text { łag } & \text { storm } \\ \text { hał } & \text { sun } \\ \text { hałap } & \text { lineage head } \\ \text { hałłag } & \text { stare }\end{array}$

h\&k tired

harh your (sg.)

temah light bulb

kertutian make, do

n an $n$-sound made with

the tongue tip

curled back to

touch the roof of

nath

kan,

ran

mosquito

the mouth (no close

equivalent in

henehneh happy

English); has a

$\mathrm{k}$ \&ninat

a tree: scaveola frutescens

'dark' $r$-color

r
a trilled $r$--tongue tip trilled against front part of roof of mouth, behind gum ridge

$t$ tongue touches the upper teeth instead of the gum ridge behind them; no puff of breath; more like English $d$ singly between vowels, but like $d t$ of had to when double

$\begin{array}{ll}\text { rah } & \text { branch } \\ \text { bar } & \text { head; rock } \\ \text { berah } & \text { my head } \\ \text { berray } & \text { to split } \\ \text { tab } & \text { fog, haze } \\ \text { bat } & \text { hili; slow } \\ \text { betah } & \text { butter } \\ \text { bettah } & \text { batter (baseba11) }\end{array}$

\section{Rounded consonants}

The rounding referred to in this name is the rounding of the lips when these consonants and neighboring vowels are pronounced. These consonants are more closely related to the heavy consonants than they are to the plain ones. Thus gै can be considered a g pronounced with concomitant Iip rounding; similarly, $\underline{\underline{1}}$ is a rounded $\underline{z}, \underline{H}$ a rounded $\underline{\mathrm{n}}$, $\mathrm{g}$ a rounded $\underline{\mathrm{k}}, \underline{\underline{\mu}}$ a rounded $\underline{r}$, and $\underline{w}$ a rounded $\underline{h} \cdot$. This rounding cärries over to contiguous vowels, and converts the value of $\underline{i}$ to a value close to the 00 of food, $\underline{\&}$ to the 00 of 


\section{xviii}

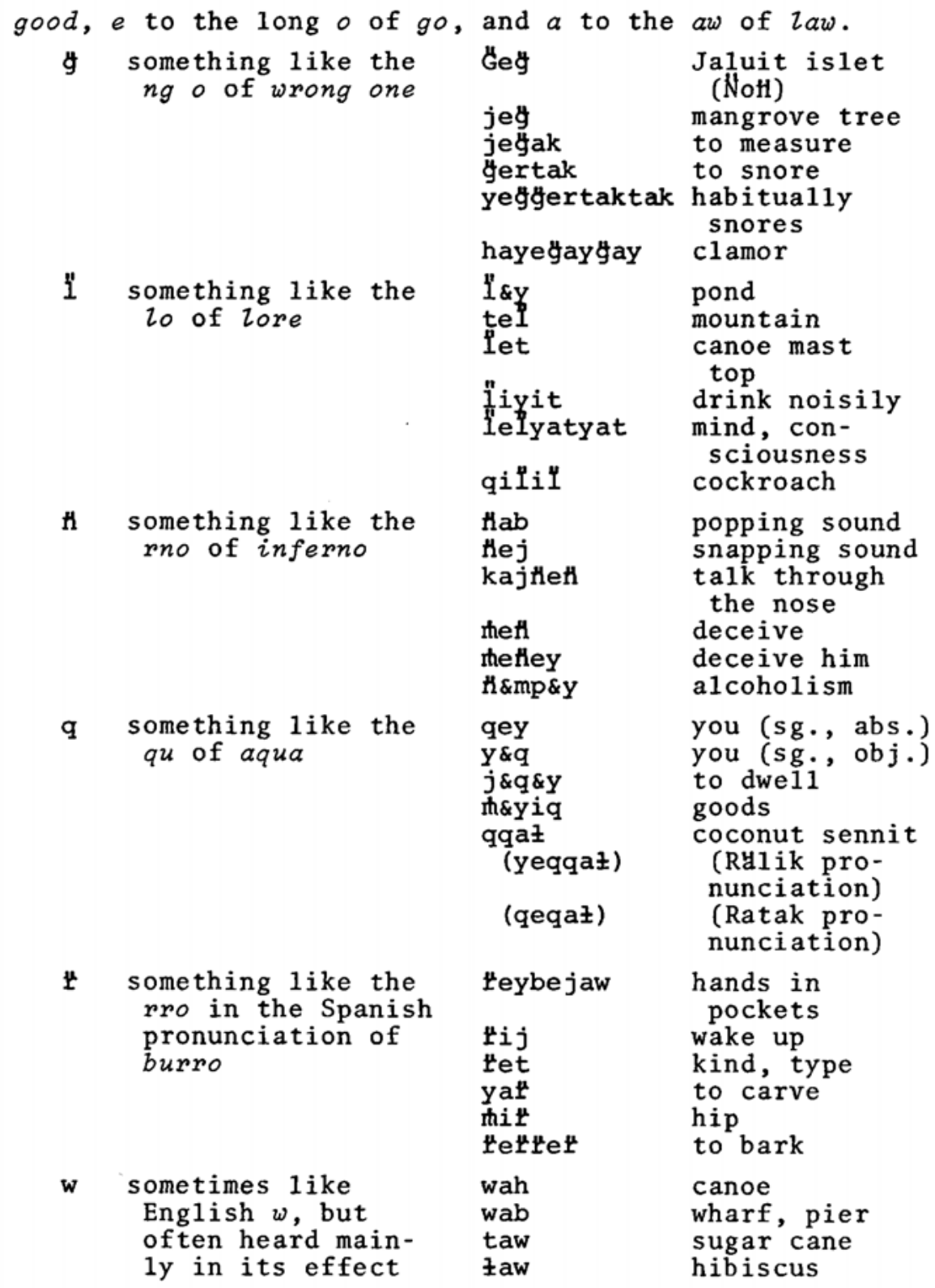


xix

\begin{tabular}{|c|c|c|}
\hline $\begin{array}{l}\text { on neighboring } \\
\text { vowels }\end{array}$ & $\begin{array}{l}\text { waw\&w } \\
\text { jewwan }\end{array}$ & $\begin{array}{l}\text { the letter } \\
\text { 'o' } \\
\text { lazy }\end{array}$ \\
\hline
\end{tabular}

The following minimally contrasting pairs of words serve to isolate and highlight the rounding effect of the rounded consonants:

$\begin{array}{llll}\begin{array}{l}\text { bek } \\ \text { beq }\end{array} & \begin{array}{l}\text { bring, take } \\ \text { sand }\end{array} & \begin{array}{l}\text { mag } \\ \text { mag }\end{array} & \begin{array}{c}\text { fall } \\ \text { pate }\end{array} \\ \text { key } & \text { question particle } & \text { jehet } & \text { shirt } \\ \text { qey } & \text { you (sg., abs.) } & \text { jewet bullet } \\ \text { bekey take it } & \text { łag } & \text { storm } \\ \text { beqey sandy } & \text { zag } & \text { house fly }\end{array}$

Summary of consonant sounds

light heavy rounded

Semiconsonants

Stops . . . .

$\begin{array}{lllll}\text { Ve1ar - oral } & \text { y } & \text { h } & \text { w } \\ & \text { - nasa1 } & - & \text { k } & \text { q } \\ \text { Labial - ora1 } & \text { p } & \text { b } & \text { g } \\ & \text { nasal } & \text { m } & \text { it } & - \\ \text { Dental - ora1 } & \text { j } & \text { t } & - \\ & \text { - nasal } & \text { n } & \text { h } & \text { H } \\ \text { Lateral } & \text { l } & \text { z } & \text { I } \\ \text { Trill } & \text { d } & \text { r } & \text { r }\end{array}$

Note that symbols with a single mark (h, $n, \pm$ ) all represent heavy sounds, while those with a double mark ( $g, H, 1, H)$ all represent rounded sounds.

Their effects on the vowels

In choosing examples to illustrate the light and heavy consonants above, an attempt was made to find words whose consonants were all of one type or the other, so that the effect of each type on vowels would be most clear. (This was not possible for the rounded consonants because words containing them are relatively rare.)

Now it may prove helpful to consider what happens when the consonants in a word are of more than one type-. when a vowel is caught between the competing influences of consonants of differing types. This can probably be illustrated best by observing words of one syllable, of the pattern: consonant-vowel-consonant. These are 
grouped below according to the various combinations, with the three semiconsonants ( $y, h, w)$ serving as cover labels for the consonants of their respective types:

$$
\underline{y}-\underline{h}
$$

lim

jik

I\&b

$p \& t$

yeb

yen

dart

jar

biw

tiw

$\mathrm{b} \& \mathrm{q}$

$t \& W$

tel

tew

ter

rew

taw

$\begin{array}{ll} & \underline{y}-\underline{w} \\ \text { diw } & \text { to boil } \\ \text { jiw } & \text { perpendicular } \\ \text { p\&w } & \text { ripe pandanus key } \\ & \text { j\&w } \\ \text { jeq } & \text { alight } \\ \text { mew } & \text { to heal } \\ \text { yaw tattoo } \\ \text { jaw }\end{array}$

$\begin{array}{ll} & \underline{h}-\mathrm{y} \\ \text { hil } & \text { behavior } \\ \text { kij } & \text { louse } \\ \text { b\&l } & \text { taro pit } \\ \text { t\&p } & \text { wood shavings } \\ \text { bey } & \text { enough; because } \\ \text { hey } & \text { that by you } \\ \text { had } & \text { loiter } \\ \text { raj } & \text { whale } \\ & \text { w - h } \\ \text { wib } & \text { soft, tender } \\ \text { wit } & \text { flower } \\ \text { q\&b } & \text { bent } \\ \text { w\&t } \text { rain } \\ \text { let canoe mast top } \\ \text { wet only } \\ \text { Het } \text { kind, type } \\ \text { wer fish gills } \\ \text { wat puffer fish }\end{array}$

$\underline{\mathbf{w}}-\mathbf{y}$

wid piece

wij drown; cork; uproot

w\&p a tree: Barringtonia asiatica

w\&j toward you (RHlik)

qej congeal

wem pull something out

way injection

waj watch

Note that the two columns above are mirror images of

each other. This feature can be used in a pronuncia-

tion drill, combining counterparts from the two columns as nonsense words--for example: limhil, hillih; jikkij, kijjik; $1 \& b b \& 1, b \& 11 \& b$, etc.

Words beginning in yiy... and wiw...

Most words beginning in yiy differ in pronunciation between the two dialects in a way very similar to that of words beginning in double consonants such as lliw.

'angry', tt\&x 'run', ggał 'coconut sennit', thihan 'good', 
etc. (discussed in the second grammatical note of Lesson Four). The RHlik dialect adds an extra yi, while the Ratak dialect shortens the existing yiy so that it sounds little longer than the $y$ of English yes:

\begin{tabular}{|c|c|c|c|}
\hline Word & pronunciation $\frac{\text { RHlik }}{}$ & pronunciation & Meaning \\
\hline yiyaz & [yiyiyaz] & I & road \\
\hline yiyep & [yiyiyep] & [ ${ }^{\mathrm{i}}$ yep] & basket \\
\hline yiy\&y & [yiyiy\&y] & {$\left[{ }^{y i} y \& y\right]$} & centiped \\
\hline
\end{tabular}

There has been a great deal of dialect mixture with respect to these words in yiy, and a few are now usua11y given the RHlik pronunclation in both dialects. Such words are marked in the phonetic spelling by an apostrophe before the word:

$\begin{array}{ll}\text { 'yiyewen [yiyiyewen] } & \rightarrow \text { [yiyiyewen] to meet } \\ \text { 'yiy\&k } & \text { [yiyiy\&k] } \rightarrow \text { [yiyiy\&k] to mix } \\ \text { 'yiyeh } & \text { [yiyiyeh] } \rightarrow \text { [yiyiyeh] }\end{array}$

A few others are usually given the Ratak pronunciation in both dialects. This is indicated by putting the apostrophe further to the right ('towards the east'), before the second $y$, to indicate that the first part of the word is passed over very rapidly (Ratak fashion) in both dialects:

$$
\begin{aligned}
& y i ' y a h \quad\left[{ }^{i} y a h\right]+\left[{ }^{i} y a h\right] \text { where? } \\
& \text { yi'yaqey [yiyaqey } \left.] \leftarrow{ }^{1}{ }^{i} \text { yaqey }\right] \text { aloha } \\
& y{ }^{\prime y} \& y \quad\left[{ }^{i} y \& y\right]+\left[{ }^{y i} y \& y\right] \text { there }
\end{aligned}
$$

Remember: words beginning in yiy with no apostrophe are pronounced differently in the two dialects. The Rulik pronunciation dwe11s on the yiy; the Ratak pronunciation passes over it rapidly. Words with an initial apostrophe ('yiy....) are given the western 'dwelling on' pronunciation in both dialects, while those with a later apostrophe (yi'y...) are given the eastern 'passing over lightly pronunciation in both.

Words in initial wiw also receive special treatment in each dialect. The RHlik dialect again preposes yi, while the Ratak dialect adds an additional wi instead:

$\begin{array}{llll}\text { wiw\&y } & \text { [yiwiw\&y] } & \text { [wiwiw\&y] } & \text { ride, get on } \\ \text { wiwan } & \text { [yiwiwah] } & \text { [wiwiwan] } & \text { gray haired } \\ \text { wiweyew } & \text { [yiwiweyew] } & \text { [wiwiweyew] } & \begin{array}{c}\text { that way over } \\ \text { there }\end{array}\end{array}$


$\operatorname{xxii}$

Rhythm and Intonation

The matters of pitch, loudness, and timing of the voice have not been analyzed and marked in the spelling system beyond the indication of double (long) vs. single consonants. This latter distinction--whether a sound is held or passed over quickly--is the key to both loudness (or relative prominence) and rhythm in the language, and the doubling of symbols in the phonetic spelling should help the student remember and recreate the utterances he has heard with proper loudness and timing values. The other matter the student should pay attention to and mimic his instructor closely on is the rise and fall of the voice, especially at the end of sentences. This has not been marked in the spelling, although the punctuation sometimes gives clues. In later lessons there are some drills on meaningful contrasts in intonation in which the distinctions are analyzed and discussed.

Words to the Instructor

These lessons are written in a form that assumes that the instructor has had training in modern foreign language teaching--they contain a minimum of instructions to the teacher. However, here are a few general rules of thumb that any language teacher would do we11 to keep in mind. It is suggested that they be reread at least once a week.

1. Students must memorize the material. With the exception of reference sections, all the language material in each lesson from dialogue through drill must be over-learned with accurate pronunciation from the beginning. Most drill lines will have to be modeled in their entirety at first; later the amount of cue material for each can be successively reduced until a minimal cue is reached. English cues can be used as a culminating activity.

2. Students must know what they are saying at all times. From the moment an utterance is first modeled the instructor must communicate to the student its meaning, and each time it is practiced the instructor must continue to ask himself and take measures to find out whether each student knows what he is saying. This does not mean that he should know some English equivalent for each Marshallese word (in fact, this is not good practice), but that he should have a general idea of the meaning of the entire utterance. 
3. Students must be challenged at every moment. Corol1ary: The instructor must develop a good sense of when to move on--to move from one student to another, from one drill to another, from choral to individual work, from review to new material, etc.

4. Students must be given a maximum of practice in speaking the language, never in talking about the 1 anguage. Each class hour should be evaluated in terms of the number of minutes each student was actually practicing speaking the language. Obviously, from this point of view, the more choral drill the better. Individual drill should only be used for spot checks on control of pronunciation or structure, and for variety in connection with Point 3 above. Grammar should never be discussed in class. Grammatical notes have been included for those students who feel a need to view the language analytically in addition to learning it, but the reading and discussion of them should be kept outside the class hour.

5. Students must be helped to go beyond each lesson, to apply the patterns learned in each lesson to real life situations, under the guidance of the teacher. The DDT formula which calls for dialogue and drill to be followed by 'talk' is a good one to keep in mind. As a culminating activity for each lesson, the teacher should help the students to substitute other words in the dialogues and drills--words that have more relevance to the students' own lives than could have been anticipated by the writer. As more and more lessons have been learned, such activity can begin to approach free and unstructured conversation.

6. Students must be given constant review. Although patterns and words keep recurring from lesson to lesson, no review lessons as such are provided. The teacher should make it a practice to intersperse review material from preceding lessons alongside new material from the current lessons throughout each class hour. Never overestimate the students' ability to retain. Make sure they do through constant review.

Finally, the teacher must plan each class hour thorough1y in advance. Walking into class with this book under his arm is not enough, no matter how well he knows the language. The plan must be a flexible one that $c$ an be easily modified as the class hour develops. But there must be a plan. 
xxiv

7. Learn the phonetic spelling. Although the traditional spelling will seem more familiar to you at first, you will not find the phonetic spelling difficult to master. It will give you new insights into the sound system of your language and the problems your students face in acquiring a good pronunciation.

\section{Getting Started--Useful Expressions}

Hezlo. Goodbye.

Yokwe.

HeZZo. Goodbye.

Yokwe yok.

HeZzo. Goodbye

Yokwe kom.

Thank you.

Kommol.

Thank you.

Kom emmol.

You're we lcome.

Kin joij. (to one or more)

Yi'yaqey.

(to one person)

Yi 'yaqey $y \& q$.

(to more than one person)

Yi 'yaqey q\&h.

(to one person)

Qertuhewel.

(to more than one person)

Q\&in mithewel.

('with kindness')

K\&n j\&wij.

'the Marshallese language'

kajin Majol

kajin Mahjez

I don't know.

Ijaje.

Yijahj\&y •

I don't know Marshallese.

Ijaje kajin Majol.

Yijahj\&y kajin Ḿahjez.

$I^{\prime} m$ studying.

Ij ekkatak.

Yij kkahtak.

I'm studying Marshallese.

Ij ekkatak kajin Maj81.

How do you say 'study' in Marshallese?

Etan 'study' ilo

kajin Majष1?

Yetan 'study' yilew

kajin Mahjez?

I didn't hear.

Ijjab roh.

Yijjab reğ.

Please say that again.

Bar ba mbk.

Bar bah thek.

It isn't clear yet.

Ejatin alikkar.
Yejjahgin halikkar. 
What time is it?

Jete awa kib?

Jetey hawah kiyyeh?

We't2 see each other again tomorrow.

Jenaj bar 10 dron ilju.

Jenahaj bar lew dewen yiljiw. 
